\title{
Access to Quality Information as a Tool for Rebuilding Trust in Service Delivery of Teachers with Visual Impairment in Nigeria
}

\author{
Victor Chuks Nwokedi (Ph. D) \& Samuel Olajide Ogundele \\ Department of Social Science Education, University of JOS, Jos Plateaustate, Nigeria
}

\begin{abstract}
Teaching is the process of inculcation knowledge, values, morals and skills needed to solve both theory and practical problems. Knowledge is gain as a result of access to quality information about a topic or subject. However, quality information can be used as an asset to enhance effective service delivery of teachers with visual impairment in Nigeria and toward rebuilding trust in the educational services provided. To this end the paper examine the need to access quality information as tool for rebuilding trust in service delivery of teachers with visual impairment, role of information in teaching and learning process, and advantage of access to quality information on service delivery of teachers with visual impairment. It was concluded that the role of information in teaching and learning process cannot be over emphasized, teachers including teachers with visual impairment need to access quality information in other to transfer quality knowledge to their learner. It is observed that information access is low among teachers with visual impairment. Suggestions is that the institutions need to provide adequate information resources in a format that can be easily access by teachers with visual impairment, and the institutional based information system should be effectively manage so that the service delivery of teachers with visual impairment can be trusted in Nigeria.
\end{abstract}

Keywords: Access, Quality Information, Rebuilding Trust, Service Delivery and Teachers with Visual Impairment

\section{INTRODUCTION}

$\mathrm{I}^{\mathrm{r}}$ nformation play important role in discharging day to day activities of individual in every profession and teaching is not an exception. The term Information mean, to inform, enlighten or create awareness on a given subject, topics or event. Ortlieb (2012) opined that, information is needed in all activities (including teaching). Information refers to knowledge, idea, thought or event that is communicated in any form from one person to another. According to Chinnasamy (2016) information is the knowledge of human in action which are communicated formally or informally. Achebe and Lucky (2013) added that information service is an exchange of information about ideas, feelings, attitudes and beliefs between sender and receiver.

However, information is a resource every teachers needs to achieve his/her teaching objective. Quality of information accessed by teachers with visual impairment can determine the quality of their services delivery in the school system. According to Harden and Crosby (2000) teacher is an expert who is knowledgeable in his/her field, and who conveys that knowledge to students usually by word of mouth, Information is that which are communicated from teacher to learner. Ever since the ways of teaching person with visual impairment were discover, reasonable amount of person with visual impairment has chosen teaching as their profession. Teachers with visual impairment are teachers with defective condition in the organ of sight. Tis categories of teachers are disabled in reading printed material. Therefore, for information resources to be use by teacher with visual impairment it has to be converted to accessible format.

Teaching as a profession depends solely on availability, accessibility and usability of quality information. When information resources are not available, accessible and useful to teachers with visual impairments, limit the quality of service delivery. Teachers knowledge can be determine by the amount of quality information they have access to. Aghauche and Udem (2018) was of the opinion that since visual impaired cannot access information in print, there is need to repackage information in a format suitable to them, that is alternative formats which include Braille, audio/talking materials, large print and ICT resources. Adetoro (2011) opine that Information materials for person with visual impaired are converted into alternative formats such as Braille, talking books/audio recording, large prints and e-resources to meet their reading interest. He further stated that, the use of alternative formats by visually impaired is limited by availability. Teachers with visual impairment encounter many challenges in the process of discharging their duties. Among the challenges facing this categories of teachers are lack of adequate and useful information resources needed for effective service delivery. Information access of teacher with visual impairment is limited in most schools in Nigeria. Majority of schools in Nigeria do not have provision for teacher with visual impairment

In Nigeria, person with visual impairment rely on the goodness of charities and philanthropist to provide them with information resources (Adetoro, 2011). School management does not usually consider teachers with visual impairment when acquiring information sources for teaching and learning. Resources available in most Nigeria schools are geared toward sighed users which imply that information need of teachers with visual impairment are not taking care of in 
Nigeria schools. According to Adetoro (2011) few schools in Nigeria make information materials available for visual impaired students. Most of the information resources available in the school, colleges or institution are not in accessible format for teachers with visual impairment. Despite the fact that they have the same goal to achieve with sighted teachers.

\section{LITERATURE REVIEW}

The term information quality refers to the truthfulness, correctness and completeness of information. According to Embury (2009) information is regarded as of high quality if it is for purpose, which can be judge by the consumer of information only. What is considered to be of high quality by a group of people may be consider as low quality by another. Thus, quality of information can be judge in term of its usefulness, relevant, accuracy, timeliness and how effective it serve the information need of the consumer or report all what the user want to know about a topic, subject or event. Information is of high quality when is contain the trusted idea, knowledge and original data.

Azemi, Zaidi \& Hussin (2017) opined that, information quality is a degree to which;

a. Measurement method used to prepare information and can represent what the information user want to know about want to know (information relevance).

b. The stated methods have been completely applied and the results truthfully displayed (information reliability or credibility). (P.45).

Information is of high quality when the receiver receives accurate, complete and useful information from the sender. According to tang (2003) there are four (4) somatic categories of information quality namely;

1. Intrinsic accuracy (objective, credibility and reputability)

2. Contextual relevance (valuableness, timeliness, completeness and information richness).

3. Representational (interpretable, understandable, conciseness and consistence).

4. Accessibility (easily and securely obtained).

\section{Type of information sources}

Information can be divided into three types namely, Primar, Secondar and Tertiary.

Primary Sources: Primary source of information is any source that first report fact about a perticular phenomenon. Primary source of information contain fact and figures that as not be analyzed my another researcher. Primary source of information include; Diaries, manuscript, journals, newspaper, conference proceeding etc.

Secondary Source: Secondary sources of information are any sources that explain, summarize or analysis the information in Primary sources. In other words, A secondary source is any source that interprets, evaluates, or analyzes information from primary sources. Any information source that explain, analysis or summary information from it original source is refers to as secondary sources of information. This includes; Textbook, encyclopedia, reviews etc.

Tertiary Sources: Tertiary sources of information are source that describe other sources of information. It give information about another sources on it use. This in include, index, abstract etc.

\section{Characteristics of Information}

According to Imeremba (2003) Sighted my Chimah and Nwokocha (2013). The value of information is based on ten attributes which includes:

1. Accessibility - the ease and speed with which an information output can be obtained.

2. Comprehensiveness - the completeness of the information content.

3. Accuracy - the degree of freedom from error of the information output

4. Appropriateness - how well the information output relates to the user's request. The information content must be relevant to the matter on hand.

5. Timeliness - it is related to a shorter elapsed time of cycle: input, processing and reporting of output to the users. Normally, for information to be timely, the duration of this cycle must be reduced.

6. Clarity - the degree an information output is free from ambiguity. Ambiguous terms or equations should be avoided.

7. Flexibility - the adaptability of an information output not only to more than one decision, but to more than one decision maker.

8. Verifiability - the ability of several users examining an information output and arriving at the same conclusion.

9. Unbiasness - the absence of intent to alter or modify information in order to produce conceived conclusion. In other words, it must be free from bias.

10. Quantifiable - the nature of information produced from a formal information system.

\section{ROLE OF INFORMATION IN TEACHING AND LEARNING PROCESS.}

Role of information in teaching and learning process cannot be over emphasized. Teaching is the transfer of knowledge that is worthwhile from the teacher to the learner. Knowledge and information are inseparable; knowledge is as a result of accumulated information. Information is what bring about teaching and learning. Information is the fuels that sustain teaching profession. In teaching, teacher select, organizes, and deliver information to the learner (Harden and Crodby, 2000). Availability of useful information resources play a significant role in teaching and learning process. When teacher have information on any subject or topic, he/she is knowledgeable about the topic/subject. The major purpose of schooling is to 
acquire knowledge that is worthwhile. Knowledge is that which the information produces. Ntui and Udah is of the opinion that, the most effective way to mobilize school teachers (including teacher with visual impairment) is through the provision of required information resources in school libraries.

According to Marylyn (2008), accommodation that as absolutely essential to teacher with visual Impairment is access to textbooks and instructional materials in the appropriate media at the same time with their sighted pair. Access and use of quality information resources motivate teachers to teach efficiently and more effectively. Access to quality information by teachers with visual Impairment will motivate them teach and also enhance the quality of lessen presented to the learner. Fullmer and Majunder sighted by Mbugua, Odeni \& Chage (2018) opined that, the ability to access and use information on any subject give an individual the opportunity to choose a path from many alternatives instead of being limited to a few perhaps unwanted or unfavorable choice. Information gives teachers with visual impairment insight about a topic or subject. Odunlade (2017) opine that, for effective teaching to take place, information resources must be provided and teachers (including teachers with visual impairment), must have access to various types of resources particularly in their areas of specialization. According to Ntui and Udati (2015) Teachers (including teacher with visual impairment) require quality information resources in order to teach effectively, undertake innovative research and use their acquired knowledge and experience to provide expert service to schools in order to turn out professional and students who will be leaders of tomorrow. when teachers access quality information, the teaching and learning will be more easier. That is why Odunlade (2017) recorded that, availability of information resources plays major role in teaching and learning. He further stated that, access to information resources by teachers (including teachers with visual impairment) will not only broaden their knowledge base but also prepare them ahead of the challenges that may face them in the course of imparting knowledge.

\section{INFORMATION AS A TOOL FOR REBUDING TRUSTS IN SERVICE DELIVERY OF TEACHER WITH VISUAL IMPAIREMENT.}

Information availability, accessibility and usability has significantly influence the service delivery of teacher with visual Impairment .Provision and utilization of information resources of various type are important in every educational setting to sustain activities (Olaopa, 2017). Odulade (2017) opine that, a variety of activities that are performed by teachers with visual Impairment in the cause of carrying out their professional duties is hinged on close interaction with various Information resources in their area of specifications. Teachers with visual impairment need to have access to information so as to effectively discharge their educational duties in the school system. According to Mbugua, Odini and Chege (2018) visually disadvantaged are likely not to participate as actively as they should in the development of a community and discharging their duties, owning this largely to their limited access to information. The teaching ability of teachers with visual impairment is mostly in dought by school stakeholder, parent and pupil or student. This can be attributed to their inability to access information with their organ of sight. Lack of trust in service delivery of visual impaired teachers is as a result of inability to access the relevant information for teaching and learning. That is why Adeoye \& Popoola (2011) stated that, the quality of teaching, research and community service of teachers in any institution depend on information sources they have access to. When teachers with visual impairment have access to information like their sighted colleague, will deliver their service effectively and efficiently in the school. Access to useful information remains the only way to rebuild trust in service delivery of teachers with visual impairment in Nigeria.

\section{CONCLUSION}

Access to quality information has being the most challenging factor that has limit the quality of services delivery of teachers with visual impairment. The study revealed that, most schools in Nigeria do not put into consideration information needs of teachers with visual impairment when acquiring information resources for teaching and learning, which in turn leave dought of quality service delivery in the mind of both parents and School management.

Based on the findings of this study one would, therefore, conclude that, teachers including teachers with visual impairment need to access quality information in other to transfer quality knowledge to their learner and school management should ensure that

\section{RECOMMENDATION}

Base on the findings of the study, researcher recommends that;

- School management should prioritize the information access of all the staffs including visually challenge staffs.

- School information system should be effectively managed so that it will serve the information need of teacher with visual Impairment

- Library should provide adequate and useful information resources in a format that can be accessible by teachers with visual impairment.

- For easy retriever of information resources by teachers with visual impairment, library must especially school/academic library must use standardize information retriever tool to organize their material.

\section{REFERENCE}

[1] Achebe,N.E \& Lucky, A.T (2013). Information Service Delivery to the Visual Impaired: A Case Study of Hope for the Blind Foundation Wusasa, Zaria, Nigeria. Research Journal of Information Technology. 5(1): 15-23. ISSN:2041-3106 
[2] Adam,M (1993). Students Perception of Teachers Effectiveness and their Class Work Examination Performance in Secondary Schools in Borno State, Nigeria. M.ed. Dessertation, University of Maiduguru,128p.(Unpublished)

[3] Adeoye, M.O \& Popoola, S.O (2011). Teaching Effectiveness, Availability, Accessibility and Use of Library and Information Resources Among Teaching Staff of Schools Nursing in Osun and Oyo State Nigeria. Library Philosophy and Practice. ISSN:15220222.Retrieved from https://digitalcommon.unl.edu/Libphilprac/525

[4] Apiah, D.K. (2017) Information SeekingBehaviour of Visually Challenge Students in Public Universities: A Study of University of Ghana, Legon and University of Education Winneba. Library Philosophy and Practice. Retrieved from https://digital Commons.unl.edu/libphi/prac/1507.

[5] Azemi, N.A, Zaidi, H \& Hussin, N (2017) Information Quality in Organization for Better Decision Making. International Journal of Academic Research in Business and Social Science. 7(12).ISSN:2222-6990.Retrieved

fromhttp://dx.doi.org/10.6007/IJARBSS/v7-i1213624.

[6] Chinnasamy, K. (2016). Information need and seeking behaviour of engineering college students in Madurai. A case study. Qualitative and quantitative methods in library. 5, 131-140

[7] Chimah, N.J \& Nwokocha, U. ( 2013). Information Resources, Retrieval and Utilization for Effective Research in Tertiary and Research Institutions. Asian Journal of Humanities and Social Sciences (AJHSS) 1( 3): 11-19. ISSN: 2320-9720

[8] Tank, R., Kwong, B., Strzlkowski, T. \& Kantor (2003)

[9] Embury, S.M, Missier, P., Sampoio, S., Greewood, R.M. \& Greece, A.D. (2009). Incorporating Domain-specific information qualitative constraints into database queries. Journal of Data \& Information Quality (JDIQ). 1(2), retrieved from http://delivery.acm.org/10.1145.1580000/1577846/911_embury.pd f?key1-1577846\&keyz-5318887521\&1011-portal\&diACM\&CFID-60913111\&CFTOKEN-59567280

[10] Global Advisory committee. Information quality: the foundation for justice decision making. Retrieved from www.IT.OJP.GOV/IQ-RESOURCES

[11] Howard, G, Lubbe, S \& Klopper, E. (2011). Impact of Information qualitative on information research. Alternation Special Edition 4, 288-305.

[12] Harden, R.M \& Crosby, J. (2000). The twelve role of the teacher: AMME Medical Education Guide. Scotland:LynnBell

[13] Ismaila, B.A (1999). The relationship between teachers characteristics and Student Academic Achievement in Secondary Schools in Adamawa State, Nigeria. Unpublished M.Ed Dissertation, University of Maiduguri. 152p.

[14] Mbuga, E.N, Odini, C. \& Chege, A. (2018). Provision of Information Service to the Visually Impaired Studentd at Thika School for the Blind. International Journal of Humanities and Social Science. 8(8), 46-56.

[15] Ntui A.I. \& Udah A.E (2015). Accessibility and Utilization of Library Resources by Teachers in Secondary Schools in Calabar Education Zone of Cross River State, Nigeria. Global Journal of Human- Social Science XV(VIII).

[16] Odunlade, R.O (2017) Availability and accessibility of information resources as predictor of lecturer teaching effectiveness. Library Philosophy and Practice. Retrieved from http://digitalcommons.unl.edu/libphi/prac/1509

[17] Ortlieb, E. (2013). Attraction Theory, Practice and Evaluation. Literacy Research. 4(3), 21-30.

[18] Popoola, S.O \& Holiso, Y. (2009). Use of Library Information Resources and services as Predictor of Teaching Effectiveness of Social Scientist. AJLAIS. 19(1), 65-77. 